\title{
Integrating Science and Society through Long-Term Socio-Ecological Research
}

\author{
Christopher B. Anderson, Gene E. Likens, Ricardo Rozzi, \\ Julio R. Gutiérrez, Juan J. Armesto, and Alexandria Poole*
}

\begin{abstract}
Long-term ecological research (LTER), addressing problems that encompass decadal or longer time frames, began as a formal term and program in the United States in 1980. While longterm ecological studies and observation began as early as the 1400s and 1800s in Asia and Europe, respectively, the long-term approach was not formalized until the establishment of the U.S. long-term ecological research programs. These programs permitted ecosystem-level experiments and cross-site comparisons that led to insights into the biosphere's structure and function. The holistic ecosystem approach of this initiative also allowed the incorporation of the human-dimension of ecology and recently has given rise to a new concept of long-term socio-ecological research (LTSER). Today, long-term ecological research programs exist in at least thirty-two countries (i.e., members of the International Long-Term Ecological Research Network, ILTER). However, consolidation of the international network within the long-term socio-ecological research paradigm still requires: (1) inclusion of certain remote regions of the world, such as southwestern South America, that are still poorly represented; (2) modifications of the type of research conducted, such as integrating social and natural sciences with the humanities and ethics; and (3) the incorporation of findings and results into broader social and political processes. In this context, a nascent long-term socio-ecological research network in Chile, which extends over the longest latitudinal range of temperate forest in the Southern Hemisphere, adds a new remote region to international long-term ecological research previously overlooked. In addition, collaboration with the University of North Texas and other international partners helps to further develop an interdisciplinary approach for the integration of the ecological sciences and environmental philosophy together with traditional ecological knowledge, informal and formal education, policy, the humanities, socio-political processes, and biocultural conservation.
\end{abstract}

\section{INTRODUCTION}

Long-term ecological research encompasses ecosystem, community, and population or species studies aimed at understanding processes that take place over decadal, or longer time frames. Such questions are not addressed by traditional

\footnotetext{
* Christopher B. Anderson, Institute of Ecology and Biodiversity, Casilla 653, Santiago, Chile; email: canderson@alumni.unc.edu; Gene E. Likens, Cary Institute of Ecosystem Studies, Millbrook, NY 12545; Ricardo Rozzi, Institute of Ecology and Biodiversity, Casilla 653, Santiago, Chile; Julio R. Gutiérrez, Institute of Ecology and Biodiversity, Casilla 653, Santiago, Chile; Juan J. Armesto, Institute of Ecology and Biodiversity, Casilla 653, Santiago, Chile; and Alexandria Poole, Department of Philosophy and Religion Studies, and the UNT Chile Program, P.O. Box 31920, University of North Texas, Denton, TX 76203-0920. Anderson and Rozzi are also associated with Omora Ethnobotanical Park, University of Magallanes, Puerto Williams, Chile. In addition, Rozzi is involved in the Department of Philosophy and Religion Studies, and the UNT Chile Program, P.O. Box 31920, University of North Texas, Denton, TX 76203-0920. Gutiérrez is also associated with Centro de Estudios Avanzados de Zonas Áridas, Departamento de Biología Universidad de La Serena, La Serena, Chile. Finally, Armesto is associated with the Center for Advanced Studies in Ecology and Biodiversity, Pontificia Universidad
} 
scientific projects, which are commonly limited to two to three years due to funding and logistical constraints. Such technical restrictions hamper our understanding of essential environmental processes affecting the functioning of the biosphere, including multi-decadal climate trends, slow ecological processes and subtle human impacts on ecosystems. ${ }^{1}$ Approaches to long-term research in ecology include "paleo" research, and cross-system comparisons. ${ }^{2}$ For example, by using paleoecological studies of fossil pollen found in ancient lake sediments, it is possible to record changes in vegetation cover and determine whether current trends are anthropogenic or part of natural cycles.

Efforts to document and understand long-term environmental trends were in place even before modern ecology. In Europe, agricultural experiments at Rothemsted Farm in England began in 1843, and a continuous observational record of ice cover has been conducted since 1443 on Suwa Lake in Japan. ${ }^{3}$ During the twentieth century, formal long-term ecological research (LTER) sites were implemented, starting in the United States, and as of May 2006, similar initiatives have been recognized in thirty-two countries by the International Long-term Ecological Research (ILTER) Network. ${ }^{4}$ Based on a holistic approach to understanding ecosystem functions, the long-term ecological research perspective also has facilitated the incorporation of human-dimensions to modern ecology. ${ }^{5}$

However, the understanding of coupled human and natural systems, even in the context of long-term initiatives, proves difficult on conceptual and practical levels for both conducting research as well as implementing subsequent policy. Integrating social variables into ecology has advanced rapidly in disciplines such as ecological economics, which offers a framework and protocols to assess the monetary value of a wide range of ecosystem services including carbon sequestration, pollination, and hydrological control. ${ }^{6}$ This approach has been criticized because of the insuf-

Católica de Chile, Casilla 114-D, Santiago, Chile.The authors thank Robert Frodeman and Francisca Massardo for valuable comments for the preparation of the manuscript, and acknowledge support from the National Science Foundation (Project No. 06524220), the Hispanic Global Initiative-University of North Texas, Institute of Ecology and Biodiversity (IEB) Grant No. P05-002-F ICM, and CONICYT PFB23-2008.

${ }^{1}$ G. E. Likens, “Toxic Winds, Whose Responsibility?” in F. H. Bormann and S. R. Kellert, eds., Ecology, Economics, and Ethics (New Haven:Yale University Press, 1991), pp. 136-52, and J. J. Armesto, "Estudios a Largo Plazo: Una Prioridad para la Investigación Ecológica de Hoy," Revista Chilena de Historia Natural 63 (1990): 7-9.

${ }^{2}$ G. E. Likens, Long-Term Studies in Ecology: Approaches and Alternatives (New York: Springer Verlag, 1989).

${ }^{3}$ J. J. Magnuson, D. M. Robertson, B. J. Benson, R. H. Wynne, D. M. Livingston, T. Arai, R. A. Assel, R. G. Barry, V. Card, E. Kuusisto, N. G. Granin, T. D. Prowse, K. M. Steward, and V. S. Vuglinski, "Historical Trends in Lake and River Ice Cover in the Northern Hemisphere," Science 289 (2000): $1743-46$.

${ }^{4}$ International Long-term Ecological Research Network at http://www.ilternet.edu.

${ }^{5}$ F. B. Golley, A History of the Ecosystem Concept (New Haven: Yale University Press, 1993).

${ }^{6}$ R. Costanza, R. d'Arge, R. de Groot, S. Farber, M. Grasso, B. Hannon, K. Limburg, S. Ñame, R.V. O’Neill, J. Paruelo, R. G. Raskin, P. Sutton, and M. van den Belt, "The Value of the World's Ecosystem Services and Natural Capital," Nature 387 (1997): 253-60. 
ficiency of placing strictly monetary values on natural processes and biodiversity, and because of the need to understand a broader suite of ecosystems values requires cultural, communal, ethical, aesthetic, and more generally philosophic perspectives as well. ${ }^{7}$ This question was addressed during the workshop on integrating environmental philosophy and ecology, to which this special issue of Environmental Ethics is dedicated.

In March 2007, scientists, philosophers, and policy analysts that participated in the workshop in southern Chile came to the conclusion that the long-term ecological research approach can facilitate the analysis of the human dimensions of the biosphere, but to achieve this potential, the following aspects must be considered: (1) long-term research must extend to understudied regions of the world, particularly "frontier" ecosystems, such as southern Chile's archipelago region identified as one of the world's last twenty-four remaining wilderness areas, ${ }^{8}$ and (2) while many formal long-term ecological research programs are currently striving to include socio-ecological dimensions into their conceptual and practical frameworks, ${ }^{9}$ integrating the humanities and other related disciplines into long-term initiatives can be better achieved under a new paradigm of long-term socio-ecological research (LTSER). ${ }^{10}$

To achieve the goal of implementing long-term research in remote areas requires overcoming significant practical, conceptual and institutional challenges, such as logistical and technical challenges related to the cost of operation, difficulty of access and communication, as well as operating field sites and hiring qualified personnel, or building infrastructure that is not harmful to the local environment, biota and cultures. ${ }^{11}$ In addition, new more effective academic and administrative structures are needed to manage such programs, which imply not only collaboration across disciplines, but also an ability to integrate different institutions, government authorities, decision makers, business managers, information technology administrators, and public communicators. ${ }^{12}$ Finally, long-term research programs must

\footnotetext{
${ }^{7}$ A. Leopold, "Thinking like a Mountain," in Sand County Alamanac (New York: Oxford University Press, 1949).

${ }^{8}$ R. A. Mittermeier, C. G. Mittermeier, T. M. Brooks, J. D. Pilgrim, W. R. Konstant, G. A. B. de Fonseca, and C. Kormos, "Wilderness and Biodiversity Conservation," Proceedings of the National Academy of Sciences 100 (2003): 10309-13.

${ }^{9}$ C. L. Redman, J. Morgan Grove, and L. H. Kuby, "Integrating Social Science into the Long-Term Ecological Research (LTER) Network: Social Dimensions of Ecological Change and Ecological Dimension of Social Change," Ecosystems 7 (2004): 161-71.

${ }^{10}$ H. Haberl, V. Winiwarter, K. Andersson, R. U. Ayres, C. Boone, A. Castillo, G. Cunfer, M. FischerKowalski, W. R. Freudenburg, E. Furman, R. Kaufmann, F. Krausmann, E. Langthaler, H. Lotze-Campen, M. Mirtl, C. L. Redman, A. Reenberg, A. Wardell, B. Warr, and H. Zechmeister, "From LTER to LTSER: Conceptualizing the Socioeconomic Dimension of Long-Term Socioecological Research," Ecology and Society 11 (2006): 13.

${ }^{11}$ R. Rozzi, F. Massardo, C. B. Anderson, K. Heidinger, and J. A. Silander, Jr., "Ten Principles for Biocultural Conservation at the Southern Tip of the Americas: The Approach of the Omora Ethnobotanical Park," Ecology and Society 11 (2006): 43, at http://www.ecologyandsociety.org/vol11/iss1/art43.

12 Ibid.
} 
be capable of articulating with broader regional, national, and international efforts to have greater relevance and support. ${ }^{13}$

Here, we describe and reflect on the process of creation and implementation of a nascent long-term socio-ecological research network in Chile that seeks to promote the integration of interdisciplinary ecological research, biocultural conservation, and society. We review the genesis and paths of similar programs in other parts of the world to evaluate their limitations and benefits. We also assess how long-term ecological research, and more recently long-term socio-ecological research, have been able adapt to changing societal demands and decision-making needs. We end by presenting and offering a vision for Chile's long-term socio-ecological research network, which covers a unique remote area of the world ${ }^{14}$ and includes participant sites that began integrating ecological sciences and environmental ethics into conservation more than a decade ago. ${ }^{15}$

\section{THE GENESIS OF LONG-TERM ECOLOGICAL RESEARCH PROGRAMS}

In the United States, precursors to a formal long-term ecological research program included the established activities of national laboratories associated with the Department of Energy, as well as the national park and reserve systems. ${ }^{16}$ As a formal term and research strategy, long-term ecological research was consolidated in 1980 through a program office in the United States National Science Foundation (NSF). ${ }^{17}$ U.S. long-term ecological research was in part the institutionalization of a disciplinary movement within the field of ecology that arose in the 1950s, based on an ecosystem perspective. ${ }^{18}$ Ecosystem ecology concomitantly required new methods and appropriate study units. Research sites were needed that permitted cross-site comparisons and large-scale field experiments to test theories and models of system properties, which extended the reach of geographically limited and temporally restricted studies. ${ }^{19}$

Beginning in the 1950s and growing out of such seminal programs as Coweeta Hydrological Laboratory and Hubbard Brook Ecosystem Study, intensive multidisciplinary research was pioneered at sites where studies were conducted systematically over several decades to disentangle "the invisible present" and link long-term lags

\footnotetext{
13 E.g., International Long-term Ecological Research Network, at http://www.ilternet.edu; World Biosphere Reserve Network, at http://www.unesco.org/mab.

14 J. J. Armesto, R. Rozzi, C. Smith-Ramírez, M. T. K. Arroyo, "Conservation Targets in South American Temperate Forests, Science 282 (1998): 1271-72.

${ }^{15}$ R. Rozzi, J. J. Armesto, F. Massardo, S. T. A. Pickett, and S. Lehmann, "Recuperando el Vínculo entre la Ciencia y la Ética: Hacia una Unidad entre Ecólogos y Ambientalistas," Ambiente y Desarrollo 12, no. 4 (1996): 81-86; R. Rozzi, “The Reciprocal Links between Evolutionary-Ecological Sciences and Environmental Ethics, BioScience 49 (1999): 911-21.

16 J. T. Callahan, "Long-Term Ecological Research," BioScience 34 (1984): 363-67.

${ }^{17}$ Ibid.

${ }^{18}$ Golley, A History of the Ecosystem Concept.

${ }^{19}$ Likens, "Toxic Winds."
} 
between cause and effect. ${ }^{20}$ The value of such projects to broader society became increasingly evident over time, as their ability to enhance understanding of environmental problems began to influence and shape social and political discourse, appearing in major media outlets such as the New York Times addressing controversial issues (e.g.,forestry practices and acid rain). ${ }^{21}$ Reviewing the role of the Hubbard Brook long-term ecological research site in these major national policy deliberations, we can learn another important lesson: it is evident that scientific information alone did not foster consensus in socio-political processes; rather, the role of the scientists themselves in the discourse was crucial.

Another characteristic recognized early on for long-term research programs was their multi-institutional nature. ${ }^{22}$ Combining the agendas of various agencies, however, is not a simple task. For instance, Coweeta and Hubbard Brook are long-term ecological research sites of the National Science Foundation, but they are located in experimental forests operated by the U.S. Forest Service. To establish of these long-term ecological research programs, scientists from nearby universities started both personal and institutional collaborations with the forest service, which expanded the impact and relevance of these studies and broadened the suite of experiments, disciplines, scientists and students working at the site. The Coweeta long-term ecological research program eventually went a step further to integrate efforts with the Great Smokey Mountains National Park (National Park Service) and the Oak Ridge National Laboratory (Department of Energy) to create the Southern Appalachian Biosphere Reserve(UNESCO). At the same time, Strayer and colleagues ${ }^{23}$ noted that the commitment of a few dedicated individuals was essential to provide the foundation for the continuity of such long-term initiatives.

While ecology was developing as a field from the 1950s onward, a parallel political movement was modifying and creating national legislation that integrated some of this ecological understanding into policy. For example, the National Environmental Policy Act (NEPA) was promulgated in $1969 .{ }^{24}$ Its effect on science was not immediate, but over time, this and other legislation, such as the Clean Water Act (1972) the Clean Air Act (1963) and the creation of the Environmental Protection Agency (1970), made it necessary to accumulate baseline environmental data for policy making and in turn helped to legitimize federal funding of long-term ecological research.

\footnotetext{
${ }^{20}$ J. J. Magnuson, "Long-Term Ecological Research and the Invisible Present," BioScience 40 (1990): 495-502.

${ }^{21}$ Likens, “Toxic Winds," pp. 136-42.

22 J. F. Franklin, C. S. Bledsoe, and J. T Callahan, "Contributions of the Long-Term Ecological Research Program," BioScience 40 (1990): 509-23.

${ }^{23}$ D. L. Strayer, J. S. Glitzenstein, C. Jones, J. Kolasa, G. E. Likens, M. McDonnell, G. G. Parker, and S. T. A. Pickett, "Long-Term Ecological Studies: An Illustrated Account of their Design, Operation and Importance to Ecology," Occasional Publication of the Institute of Ecosystem Studies (1986), pp. $1-38$.

${ }^{24}$ The National Environmental Policy Act of 1969, at http://www.nepa.gov/nepa/regs/nepa/nepaeqia. htm.
} 
At the international level, scientific-political currents in the 1970s were also promoting the integration of human well-being and the environment. The UNESCO Man and the Biosphere Program (MaB), created in 1970, started the world network of biosphere reserves, and explicitly sought to use interdisciplinary research and capacity building to improve the relationship between people and their environment. ${ }^{25}$ The International Biological Program (IBP) (1964-1974) arose in parallel as a coordinated, multidisciplinary effort to understand the Earth's systems by conducting comparative ecosystem studies across a range of biomes around the world to better manage and use protected areas to meet societal needs. ${ }^{26}$ For example, the program statement of the U.S.-IBP's terrestrial productivity working group, chaired by E. P. Odum, stated that the "primary purpose of the IBP is understanding ecosystems, including man's own." In addition, the committee's objectives placed emphasis on collaborative research and the need to conduct investigation outside of pristine areas. ${ }^{27}$

While the U.S.-IBP program was relatively short-lived, the creation of a funding mechanism for this program allowed a subsequent transition to the pilot long-term ecological research program. Shortly after the end of the IBP, the NSF adopted a similar strategy, converting six former IBP sites into the first national long-term ecological research network in the early 1980s (as of 2008 there are twenty-six long-term ecological research sites in the U.S.). In the consultative process of workshops (1977-1979) leading up to the U.S. long-term ecological research program, consensus arose around the title of long-term "research" over long-term "monitoring," denoting the participants' rejection of simply collecting data and giving emphasis to the need to have guiding hypotheses and questions. ${ }^{28}$ In this way, the long-term ecological research program has proven useful in implementing the multiple facets of ecosystem science: theory, experimentation, cross-site comparison and long-term monitoring. ${ }^{29}$ Today, however, the emphasis on adding a greater social dimension to ecology requires a new dialogue among researchers to agree on appropriate strategies and priorities. In this process, long-term research programs provide a useful tool to achieve this goal. The fact that long-term ecological research programs are site-based and have a longer time frame than traditional research grants has the potential to facilitate a sustained dialogue between researchers and local communities, authorities, and educators.

\footnotetext{
${ }^{25}$ Guevara and Laborde, "The Landscape Approach," pp. 251-62, this volume.

${ }^{26}$ Golley, A History of the Ecosystem Concept.

${ }^{27}$ Ibid.

${ }^{28}$ Callahan, "Long-Term Ecological Research."

${ }^{29}$ Quoted from Steven Carpenter; cited in M. L. Pace and P. M. Groffman, "Successes, Limitations, and Frontiers in Ecosystem Science: Reflections on the Seventh Cary Conference," Ecosystems 1 (1998): $137-42$.
} 


\section{EXPANDING LONG-TERM ECOLOGICAL RESEARCH TO INCLUDE THE HUMAN DIMENSION OF ECOLOGY}

The reawakening in science of the role of Homo sapiens in the planet's ecology was accompanied by extensive documentation of the increase in the rate, scale, and complexity of social alterations to the biosphere. ${ }^{30}$ The relationship between social and natural systems is dramatically demonstrated by human accelerated environmental change. ${ }^{31}$ Such phenomena as land-use change are now understood to yield a myriad of social, ethical and ecological consequences, including climate change, biodiversity loss, forest clearing, habitat fragmentation, acid rain, urbanization, marine dead zones, soil salinization, decreased water quality, atmospheric mercury deposition, and widespread infectious disease.

The accelerated role, scale, and magnitude of human influence in natural systems can be seen in more subtle ways, as well. The cumulative effects on land use by humans, for example, has increased the sediment transported by rivers on a global scale from a historic average (based on a 540 million year record) of 5 gigatons ( 1 gigaton $=1$ million tons) per year $\left(\mathrm{Gt} \mathrm{y}^{-1}\right)$ to a figure closer to $21 \mathrm{Gt}^{-1}$ today. Additionally, up to $75 \mathrm{Gt} \mathrm{y}^{-1}$ of rock and soil are moved by humans each year. ${ }^{32}$ The consequences of such large-scale, complex and pervasive alterations led ecologists to acknowledge and scrutinize the inherent link between social and ecological variables, and a new body of literature is arising around the concept of dynamic coupled human-nature systems. ${ }^{33}$

Concomitantly, social and political structures are changing. New countries are rising in population and international influence, such as the recent emergence of China and India as global economic and political powers. Issues of wealth distribution have also modified the global social order with the ratio of rich to poor countries increasing in all regions of the world since $1800 .{ }^{34}$ Consequently, relevant research questions now bridge social and ecological realms of inquiry, such as the ethical implications of bearing the responsibility versus the consequences involved in issues such as the trading of mercury emitted to the atmosphere or global warming-associated sea level rise. Indeed, it is often the case that the social groups and countries that act as drivers of ecological changes and environmental deterioration are not the ones who ultimately bear the consequences of such

\footnotetext{
${ }^{30}$ P. M. Vitousek, H. A. Mooney, J. Lubchenco, and J. Melillo, “Human Domination of Earth's Ecosystem," Science 277 (1997): 494-99.

${ }^{31}$ Likens, "Toxic Winds, Whose Responsibility?"

${ }^{32}$ B. H. Wilinson and B. J. McElroy, "The Impact of Humans on Continental Erosion and Sedimentation," Geological Society of America Bulletin 119 (2007): 140-56.

33 J. Liu, T. Dietz, S. R. Carpenter, M. Alberti, C. Folke, E. Moran, A. N. Pell, P. Deadman, T. Kratz, J. Lubchenco, E. Ostrom, Z. Ouyang, W. Provencher, C. L. Redman, S. H. Schneider, and W. W. Taylor, "Complexity of Coupled Human and Natural Systems," Science 317 (2007): 1513-16.

${ }^{34}$ See Table 1, p. 54, in M. S. Alam, "Global Disparities since 1800: Trends and Regional Patterns," MPRA Paper No. 1289 (2006), http://www.mpra.ub.uni-muenchen.de/1289.
} 
activities. For instance, the regions of Patagonia and the Antarctic Peninsula today receive the highest levels of UV radiation. Paradoxically, these regions are the farthest away from the centers of $\mathrm{CFC}$ emissions which generate the stratospheric ozone hole found over the austral portion of the Americas. ${ }^{35}$ Clearly addressing these environmental and ethical questions requires not only quality baseline and rate of change data, but also insertion of research and researchers into the social process and cultural context, thus achieving an integration of ecological sciences, ethics and policy. ${ }^{36}$ As has been shown in the debate over global climate change, data itself does not always improve the process of policy making and can in fact impede it, if both sides insist on the supremacy of their information. ${ }^{37}$

\section{ABILITY OF LONG-TERM RESEARCH PROGRAMS TO ADAPT TO SOCIAL NEEDS}

Long-term ecological research sites create and share databases, publish information on websites, give "value added" to both research and outreach, promote academic and extra-academic partnerships, foster international collaborations, link the site's work with education, and implement field laboratories and courses. ${ }^{38}$ Long-term ecological research initiatives throughout the world have demonstrated that this research strategy can accommodate changing scientific and social contexts and modify itself to meet current needs. Since their creation, long-term ecological research sites have expanded their scope from a strong bias toward "pristine" natural sites, often found within protected areas, to entire regions, including ruralagricultural landscapes and urban centers. On a global scale, there is still a need, however, to re-enforce and extend the concept of long-term research by including poorly known geographical areas. ${ }^{39}$

Furthermore, while certain aspects of long-term ecological research programs are common throughout all sites, the missions and specific objectives of national networks respond to particular histories and needs. Therefore, not surprisingly, many long-term initiatives explicitly integrated social aspects of ecological research from their inception. The U.S. long-term ecological research program, described above, is largely the product of an academic tradition that sought to understand the patterns and processes of ecosystems at multiple spatial and temporal scales. On the other hand, while the U.S. International Long-term Ecological Research Committee was

\footnotetext{
${ }^{35}$ K. Jax and R. Rozzi, "Ecological Theory and Values in the Determination of Conservation Goals: Examples from Temperate Regions of Germany, USA, and Chile," Revista Chilena de Historia Natural 77 (2004): 349-66.

${ }^{36}$ S. R. Carpenter and C. Folke, "Ecology for Transformation," Trends in Ecology and Evolution 21 (2006): 309-15.

${ }^{37}$ D. Sarewitz, "How Science Makes Environmental Controversies Worse," Environmental Science and Policy 7 (2004): 385-403.

${ }^{38}$ J. E. Hobbie, S. R. Carpenter, N. B. Grimm, J. R. Gosz, and T. R. Seastedt, "The U.S. Long-Term Ecological Research Program," BioScience 53 (2003): 21-32.

${ }^{39}$ See map at http://ilternet.edu.
} 
helpful in assisting Brazil implement its national program, via visiting scientists, grants, and workshops, the Brazilian network was established with the vision of managing watersheds, improving human health, promoting conservation, providing information on biodiversity, and implementing the Agenda 21 of the Convention for Biodiversity. Thus, the Brazilian program was explicitly linked with decision making from its creation. ${ }^{40}$ Likewise, the Southern Africa Ecological Observatory Network focuses largely on problem solving, acknowledging that most countries are challenged with meeting basic human needs. ${ }^{41}$ In turn, the southern African example also makes it clear that the long-term ecological research network is a tool for governments to fulfill commitments to international environmental conventions and treaties.

In many regions of the world, national challenges such as those described above for the southern African network are also embodied in the problems faced by individual field stations, where less than half of operating budgets are stable from year to year. ${ }^{42}$ Prioritizing long-term funding programs is one approach that may help overcome some of those hurdles for at least some, priority study sites. For instance, the long-term ecological research network in Costa Rica has partially surmounted this type of problem by partnering with the Organization for Tropical Studies (OTS), which has conducted research in three field stations since the 1960s. As a well-funded non-profit organization with headquarters in both the U.S. and Costa Rica, OTS has been uniquely positioned to coordinate the Costa Rican long-term ecological research network.

\section{CHILE'S NASCENT LONG-TERM SOCIO-ECOLOGICAL RESEARCH NETWORK}

Despite calls to create an long-term ecological research program in Chile since $1990,{ }^{43}$ little formal progress was made on this topic at the national level. However, the need and justification for such an initiative is greater than ever. Chile's participation in various international conventions (such as the Convention on Biological Biodiversity, the Ramsar Convention on Wetlands, the Montreal Protocol, and the Kyoto Protocol) necessitates better baseline information about Chilean ecosystems. Furthermore, the relatively recent formation of a Chilean National Environment Commission and the Chilean Environmental Base Law (Law 19.300, created in

\footnotetext{
${ }^{40}$ F.A.R. Barbosa, F.R. Scarano, M.G. Sabara, and F.A. Esteves, "Brazilian LTER: Ecosystem and Biodiversity Information in Support of Decision Making," Environmental Monitoring and Assessment 90 (2004): 121-33.

${ }^{41}$ J. Henschell, J. Pauw, F. Banyikwa, R. Brito, H. Cabwela, T. Palmer, S. Ringrose, L. Santos, A. Sitoe and A. van Jaarsveld, "Developing the Environmental Long-Term Observatories Network of Aouthern Africa (ELTOSA)," South African Journal of Science 99 (2003): 100-08.

${ }^{42}$ See the survey of tropical biological stations in S. Whitesell, R. J. Lilieholm, and T. L. Sharik, "A Global Survey of Tropical Biological Field Stations," BioScience 52 (2002): 55-64.

${ }^{43}$ Armesto, "Estudios a Largo Plazo."
} 
1994) requires improved ecosystem assessment capabilities for decision making. Yet, systematic environmental data from major ecosystems are largely lacking, thus limiting our ability to assess the impact of development projects.

It is in this context that the Institute of Ecology and Biodiversity (IEB), created in 2005 with financing from the Millennium Scientific Initiative (ICM in Spanish) of the Ministry of Planning, is today equipped to begin a nascent Chilean longterm socio-ecological research network. The ICM's funding cycles are in five year increments, a structure similar to the U.S. long-term ecological research funding sequence, which is renewable every six years. Also, since its inception, IEB has been a multi-institutional initiative that has privileged collaboration and networking, including researchers at five national and regional universities and two academic, field-based NGOs. ${ }^{44}$ Three of these research groups have pioneered long-term research at sites in Fray Jorge National Park (Fray Jorge), Senda Darwin Biological Station (SDBS), and Omora Ethnobotanical Park (Omora) (table 1). Researchers at these sites have systematically implemented continuous studies of population and ecosystem processes for up to nineteen years. By integrating these sites via a coordinated network, IEB is in practice creating the first comprehensive plan to implement long-term research in the longest latitudinal gradient in the Southern Hemisphere, going from semiarid Mediterranean to subantarctic latitudes (30$\left.55^{\circ} \mathrm{S}\right)$.

Accordingly, IEB has taken similar steps to those taken by the U.S. NSF in 1980, when former IBP sites were made into the first long-term ecological research network. However, the birth of the Chilean program comes at a time when the social dimension of ecology and conservation are widely recognized; hence, long-term socio-ecological research is considered a founding paradigm of the Chilean network. To further consolidate these efforts, IEB was awarded additional support by the Chilean National Science and Technology Commission (CONICYT) under the Basal Financing Program in March 2008. Significantly, these grants are explicitly part of a national strategy to promote high quality science linked to the social and economic development agenda of the country, including agriculture, aquaculture, mining and tourism, all of which are favored by the implementation of this longterm socio-ecological research network. ${ }^{45}$

While there are potential disadvantages for a national program being coordinated and initiated by a single institution, such as instability or inconsistency if problems arise within the institution, the fact that IEB is actually a network of researchers associated with several universities and organizations in the country may enhance the likelihood of persistence of the program. As shown in the example of OTS in Costa Rica, this structure is not without precedent, and when implementing long-term programs in the developing world and remote ecosystems, creative solutions are

\footnotetext{
${ }^{44}$ Institute of Ecology and Biodiversity at http://www.ieb-chile.cl.

${ }^{45}$ Consejo Nacional de Innovación para la Competitividad, Hacia una Estrategia Nacional de Innovación, vol. 2 (2008) at http://www.consejodeinnovacion.cl/cnic/cnic/web/portada.php.
} 


\section{Long-Term Socio-Ecological Research Sites}

\begin{tabular}{|c|c|c|c|}
\hline Study Site & Fray Jorge & Senda Darwin & Omora Park \\
\hline Latitude & $30^{\circ} \mathrm{S}$ & $42^{\circ} \mathrm{S}$ & $55^{\circ} \mathrm{S}$ \\
\hline $\begin{array}{c}\text { Primary } \\
\text { institutional } \\
\text { Affiliations }\end{array}$ & $\begin{array}{l}\text { Univ. de La Serena, Chilean } \\
\text { Forestry Service (CONAF), } \\
\text { IEB, Univ. of Northern } \\
\text { Illinois, Univ. of California- } \\
\text { Davis }\end{array}$ & $\begin{array}{l}\text { Senda Darwin Foundation, } \\
\text { CASEB, Pontificia Univ. } \\
\text { Católica de Chile, IEB, Univ. } \\
\text { de Chile }\end{array}$ & $\begin{array}{l}\text { Omora Foundation, Univ. de } \\
\text { Magallanes, IEB, Univ. of } \\
\text { North Texas, Center for } \\
\text { Environmental Philosophy, } \\
\text { OSARA }\end{array}$ \\
\hline Year Initiated & 1989 & 1995 & 2000 \\
\hline Land Tenure & National Park Service & $\begin{array}{l}\text { Private: Senda Darwin } \\
\text { Foundation }\end{array}$ & $\begin{array}{l}\text { Public Lease: Ministry of } \\
\text { Land to Omora Foundation } \\
\text { and Univ. of Magallanes }\end{array}$ \\
\hline $\begin{array}{c}\text { Conservation } \\
\text { Status }\end{array}$ & $\begin{array}{l}\text { National Park \& UNESCO } \\
\text { Biosphere Reserve }\end{array}$ & Private reserve & $\begin{array}{l}\text { CONAMA National Priority } \\
\text { Conservation Area, UNESCO } \\
\text { Biosphere Reserve, Land } \\
\text { Ministry "Conservation } \\
\text { Zone" }\end{array}$ \\
\hline $\begin{array}{c}\text { Principal } \\
\text { Ecosystems }\end{array}$ & $\begin{array}{l}\text { Matorral and relict Valdivian } \\
\text { forests }\end{array}$ & $\begin{array}{l}\text { Valdivian and North } \\
\text { Patagonian rain forests, peat } \\
\text { bogs, riparian vegetation }\end{array}$ & $\begin{array}{l}\text { Sub-Antarctic forests, bogs } \\
\text { and marine channels, rivers, } \\
\text { lakes }\end{array}$ \\
\hline $\begin{array}{l}\text { Current } \\
\text { Funding }\end{array}$ & $\begin{array}{l}\text { CEAZA (Conicyt) \& IEB } \\
\text { (Mideplan, Conicyt) }\end{array}$ & $\begin{array}{l}\text { CASEB (Conicyt) \& IEB } \\
\text { (Mideplan, Conicyt) }\end{array}$ & $\begin{array}{l}\text { Univ. of Magallanes, IEB } \\
\text { (Mideplan, Conicyt), Univ. } \\
\text { of North Texas, OSARA }\end{array}$ \\
\hline $\begin{array}{l}\text { Primary } \\
\text { Research } \\
\text { Lines }\end{array}$ & $\begin{array}{l}\text { One of the world's longest } \\
\text { vertebrate exclusion } \\
\text { experiments; abiotic and } \\
\text { biotic effects on small } \\
\text { mammals, vertebrate } \\
\text { predators and plants, and } \\
\text { their trophic connections; El } \\
\text { Niño Southern Oscillation } \\
\text { (ENSO). }\end{array}$ & $\begin{array}{l}\text { Population ecology of } \\
\text { understory birds inhabiting } \\
\text { rain forest fragments, forest } \\
\text { dynamics, plant-disperser } \\
\text { and pollinator interactions, } \\
\text { biogeochemistry, ecosystem } \\
\text { studies and education. }\end{array}$ & $\begin{array}{l}\text { Ethnoecology, environmental } \\
\text { philosophy, ecotourism, } \\
\text { biocultural conservation, bird } \\
\text { banding, exotic invasive } \\
\text { species, nonvascular flora, } \\
\text { lichens and algae, flagship } \\
\text { species, environmental } \\
\text { policy, education, and } \\
\text { biocultural conservation }\end{array}$ \\
\hline $\begin{array}{c}\text { Existing } \\
\text { Databases }\end{array}$ & $\begin{array}{l}\text { Small mammal populations, } \\
\text { vascular plant cover, seed } \\
\text { banks, insect and bird } \\
\text { inventories }\end{array}$ & $\begin{array}{l}\text { Bird and insect inventories, } \\
\text { vascular plant collection, } \\
\text { permanent forest plots, } \\
\text { ethnobotanical information }\end{array}$ & $\begin{array}{l}\text { Forest bird censuses, vascular } \\
\text { and non-vascular plant } \\
\text { inventories, biological and } \\
\text { cultural diversity assessment } \\
\text { of CHBR, community } \\
\text { perceptions of flora and } \\
\text { fauna }\end{array}$ \\
\hline Web Page & www.bios.niu.edu/frayjorge & www.sendadarwin.cl & www.omora.org \\
\hline
\end{tabular}

Table 1. Three existing study sites will be linked via the Institute of Ecology and Biodiversity (IEB)'s Long-Term Socio-Ecological Research Network. CASEB is the Center for Advanced Studies in Ecology and Biodiversity, CEAZA is the Center for Advanced Studies in Arid Zones, CHBR is the UNESCO Cape Horn Biosphere Reserve, CONICYT is the Chilean National Science and Technology Commission, Mideplan is the Millennium Science Initiative Program of the Ministry of Planning of Chile, and OSARA is the Omora Sub-Antartic Research Alliance. 
fundamental to achieve success. IEB must now rapidly learn from other experiences and continue to innovate, strengthen, and broaden this long-term socio-ecological research network to institutionalize the concept in the administrative framework of science and policy in Chile.

Callahan provided an appropriate starting point, laying out the U.S. NSF's criteria in the original call for proposals to create the first long-term ecological research program.$^{46}$ To ensure continuity, proposals were required to demonstrate how leadership would be ensured in the project, how the site's integrity would be guaranteed, and how conflicts over site use would be resolved. Furthermore, it was necessary to determine information generation, storage and use, which today takes the form of data management systems. Finally, proposed sites were expected to meet the challenge of synthesizing and communicating scientific information to generally promote the site to broader audiences. These proposals were made on a site level, as each group would know the best ways to overcome these challenges. To assess the pilot program in Chile, as it relates to these factors, it is useful to take a more detailed look at the three initial sites, which have complementary experiences and as each site largely reflects the context of the time period in which it was founded.

The most northern study site $\left(30^{\circ} \mathrm{S}\right)$ is found in Fray Jorge National Park, a protected area created in 1943 to preserve semiarid ecosystems and the northernmost outposts of temperate rainforest, maintained by fog on coastal mountaintops. The area was declared a world biosphere reserve in 1977. The park's long-term ecological research program dates from 1989 and has focused principally around the question of determining the abiotic and biotic factors that regulate the abundance of small mammals, vertebrate predators, and plants and their trophic connections. ${ }^{47}$ This goal has been accomplished by one of the world's longest and largest vertebrate exclusion experiments. Furthermore, given the longevity of the project, it has been possible to distinguish three complete cycles of El Niño Southern Oscillation, which have determined pronounced oscillations in rainfall, and consequently annual changes in plant cover and productivity of desert vegetation. ${ }^{48}$

The duration and impact of the Fray Jorge program has been enhanced by local scientists, based at the University of La Serena, having a productive and effective collaboration with colleagues from the United States (Northern Illinois University and University of California, Davis). These collaborations have allowed the leveraging of both national and international funding. Recently, this effort was supported with the creation of the Center of Advanced Studies in Arid Zones (CEAZA in Spanish), a regional research center funded by the Chilean National

\footnotetext{
${ }^{46}$ Callahan, "Long-Term Ecological Research."

${ }^{47}$ P. L. Meserve, D. A. Kelt, W. B. Milstead, and J. R. Gutiérrez, "Thirteen Years of Shifting TopDown and Bottom-Up Control," BioScience 53 (2003): 633-46.

48 J. R. Gutiérrez, M. Holmgrend, R. Manriquea, and F. A. Squeo, "Reduced Herbivore Pressure under Rainy ENSO Conditions Could Facilitate Dryland Reforestation," Journal of Arid Environments 68 (2007): 322-30.
} 
Science Foundation. CEAZA focuses on the study of the regional arid biome, and through its collaboration with IEB since 2005, an outreach component has been added to the Fray Jorge site to integrate science and local communities.

The second site in IEB's network is found on Chiloé Island $\left(42^{\circ} \mathrm{S}\right)$, where the Senda Darwin Biological Station was established in 1995 by Chilean and international researchers to provide a base camp for ongoing ecological studies of temperate rain forest ecosystems in fragmented rural-agricultural landscapes. ${ }^{49}$ From its establishment, the Senda Darwin Biological Station has attempted to embody a multi-faceted approach that integrated research, education, and application, inspired by the Ecological Society of America's Sustainable Biosphere Initiative ${ }^{50}$ Senda Darwin has excelled as a center for ecosystem research, linked with both the University of Chile, the Catholic University of Chile, and internationally with the Cary Institute of Ecosystem Studies in the U.S.

In contrast to Fray Jorge, the Senda Darwin site lacks a permanent cadre of locally based scientists and students living in the region. Consequently, research has been conducted by scientists and students based in central Chilean and international universities, causing an emphasis on summer studies. The Senda Darwin Biological Station's long-term research has been focused mainly on the population ecology and conservation of understory birds inhabiting rain forest fragments in the surrounding rural-agricultural landscape,${ }^{51}$ understanding long-term forest dynamics and processes, ${ }^{52}$ and the variability of plant-disperser and pollinator interactions. ${ }^{53}$ It also has a long-term collaboration with Chiloé National Park, where researchers have conducted landmark ecosystem studies on nutrient cycling and biogeochemistry in unpolluted old-growth temperate forests watersheds. ${ }^{54}$ Since 1996 , a continuous education program has developed and facilitated contact between scientists,

49 J. J. Armesto, R. Rozzi, and M. F. Willson, "Bridging Scientific Knowledge, Education and Application in Temperate Ecosystems of Southern South America," Bulletin of the Ecological Society of America 77 (1996): 120-22.

${ }^{50}$ R. Rozzi, J. Silander, Jr., J. J. Armesto, P. Feinsinger, and F. Massardo, “Three Levels of Integrating Ecology with Conservation of South American Temperate Forests: The Initiative of the Institute of Ecological Research Chiloé, Chile," Biodiversity and Conservation 9 (2000): 1199-1217.

${ }^{51}$ M. F. Willson, T. L. De Santo, C. Sabag, and J. J. Armesto, "Avian Communities of Fragmented South-Temperate Rain Forests in Chile," Conservation Biology 8 (1994): 508-20; and K. E. Sieving, M. F. Willson and T. L. De Santo, "Defining Corridor Functions for Endemic Birds in Fragmented South-Temperate Rain Forest," Conservation Biology 14 (2000): 1120-32.

52 J. C. Aravena, M. R. Carmona, C. A. Pérez, and J. J. Armesto, "Changes in Tree Species Richness, Stand Structure ,and Soil Properties in a Successional Chronosequence in Northern Chiloé Island, Chile," Revista Chilena de Historia Natural 75 (2002): 339-60.

${ }^{53}$ C. Smith-Ramírez, P. Martínez, M. Nuñez, C. González, and J. J. Armesto, "Diversity, Flower Visitation Frequency and Generalism of Pollinators in Temperate Rain Forests of Chiloé Island, Chile," Botanical Journal of the Linnean Society147 (2005): 399-416.

${ }^{54}$ L. O. Hedin, J. J. Armesto, and A. H. Johnson, "Patterns of Nutrient Loss from Unpolluted, OldGrowth Temperate Forests: Evaluation of Biogeochemical Theory," Ecology 76 (1995): 493-509; C. A. Perez, L. O. Hedin, and J. J. Armesto, "Nitrogen Mineralization in Two Unpolluted Old-Growth Forests of Contrasting Biodiversity and Dynamics," Ecosystems 1 (1998): 361-73. 
graduate students, and the local community of landowners and school teachers. In collaboration with Chilean Ministry of Education, the Senda Darwin Biological Station adapted the "schoolyard inquiry cycle" 55 to an "everyday environment," using this education tool for improving the awareness of park guards and local landowners. ${ }^{56}$

\section{INTEGRATING BIOCULTURAL CONSERVATION AND ENVIRONMENTAL PHILOSOPHY}

The southernmost site in the Chilean long-term socio-ecological research network, found in the Cape Horn Biosphere Reserve, is the Omora Ethnobotanical Park $\left(55^{\circ} \mathrm{S}\right)$. From its beginning in 1999, Omora park has involved scientists, philosophers, artists, and other professionals from Chile and abroad. This interdisciplinary team worked to unify research, education and conservation and placed a strong emphasis on what became the park's slogan: "linking biocultural conservation and social well-being from the southern end of the Americas." 57

The approach used by Omora integrates environmental ethics and traditional ecological knowledge (TEK) into conservation strategies for both biological and cultural diversity. Ethno-ornithology provides a central research line for blending scientific and indigenous perspectives on the habitats and habits of birds and humans. In Yahgan, omora signifies the green-backed firecrown hummingbird (Sephanoides sephaniodes), but it also occupies a central place in Yahgan cosmology, whereby it is understood to be a bird and at the same time a small person-spirit that maintains social and ecological order. In fact, many indigenous narratives about birds begin with the statement "in ancestral times when birds were humans." 58 Through the recording and analysis of ethno-ornithological traditional ecological knowledge, Omora researchers concluded that

Ornithological narratives of the Yahgan and Mapuche people in southern Chile permit us to expand our ways of knowing about and inhabiting nature and of living together with the birds and their ecosystems. ... [They] not only contrast scientific views; we also find substantial similarities between them. For example, the indigenous narratives share two central notions with the contemporary, ecological-evolutionary perspective: (1) the sense of biotic communities or ecological networks, of which humans and birds form part, and (2) the sense of kinship between human beings and birds, derived from common genealogies or evolutionary histories. ... From the point of view of contem-

${ }^{55}$ P. Feinsinger, L. Margutti, R. D. Oviedo, "School Yards and Nature Trails: Ecology Education Outside the University," Trends in Ecology and Evolution 12 (1997): 115-20

${ }^{56}$ See http://www.sendadarwin.cl. See also Rozzi, R., P. Feinsinger, and R. Riveros, "La Enseñanza de la Ecología en el Entorno Cotidiano," Módulo de Educación Ambiental (Santiago, Chile: Ministerio de Educación de Chile 1997).

${ }^{57}$ Rozzi et al., "Ten Principles for Biocultural Conservation."

${ }^{58}$ R. Rozzi, "Implicaciones Éticas de Narrativas Yaganes y Mapuches Sobre las Aves de los Bosques Templados de Sudamérica Austral," Ornitología Neotropical 15 (2004): 435-44. 
porary environmental ethics, the three cultural perspectives-Mapuche, Yahgan and scientific - emphasize the intrinsic value of avifauna because the birds are our distant evolutionary relatives. This implies that, to some degree, the existence of birds can be subject to moral considerations based on ontological and ethical judgments on par with those we use to judge the value of human life. ${ }^{59}$

This biocultural approach has allowed the Omora program to overcome anthropocentrism by focusing attention on the bird species and its habitats, and the hummingbird itself was an appealing image for diverse stakeholders in Puerto Williams. By directing public attention toward a species that was both biologically and culturally interesting, it furthermore helped reverse some socio-cultural prejudices that Yahgan people were facing. Plus, it invited the Yahgan community to participate in a substantive and respectful way in the park's educational and research programs. ${ }^{60} \mathrm{As}$ a result, omora became a flagship species that not only provided the name for the park, but grew to embody a comprehensive and appealing image for the program's overall ecological and social goals. The utility of flagship species for conservation initiatives also has been demonstrated to have a positive impact on ecotourism and site identity ${ }^{61}$ For these reasons, flagship species are currently being identified and implemented at all three Chilean long-term socio-ecological research sites.

The integration of sciences and philosophy at Omora park has been effectively translated into regional biocultural conservation through the creation of the Cape Horn Biosphere Reserve designated by UNESCO in $2005 .{ }^{62}$ This biosphere reserve protects the southernmost forest ecosystems of the world and was the result of a six-year collaborative effort between the regional government and the Omora team. Subsequently, scientists and philosophers working together identified a set of ten guiding principles that were essential to integrate research, policy, and conservation:

(1) inter-institutional cooperation

(2) a participatory approach

(3) an interdisciplinary integration of sciences, philosophy, arts, and policy

(4) networking and international partnership

(5) communication through the media

(6) identification of flagship species

\footnotetext{
${ }^{59}$ R. Rozzi, F. Massardo, C. Anderson, S. McGehee, G. Clark, G. Egli, E. Ramilo, U. Calderón, C. Calderón, L. Aillapan, and C. Zárraga, Multi-Ethnic Bird Guide of the Austral Temperate Forests of South America (Punta Arenas, Chile: Fantastico Sur and Universidad de Magallanes, 2003).

${ }^{60}$ Rozzi et al., "Field Environmental Philosophy and Biocultural Conservation," pp. 325-36, this issue.

${ }^{61}$ M. Walpole and N. Leader-Williams, "Tourism and Flagship Species in Conservation," Biodiversity and Conservation 11 (2002): 543-47.

${ }^{62}$ R. Rozzi, F. Massardo, C. B. Anderson, A. Berghoefer, A. Mansilla, M. Mansilla, J. Plana, U. Berghoefer, E. Barros, and P. Araya, The Cape Horn Biosphere Reserve (Punta Arenas, Chile: Ediciones de la Universidad de Magallanes, 2006).
} 
(7) "direct encounters" with human and nonhuman beings living in their habitats

(8) economic sustainability and ecotourism

(9) territorial planning and administrative sustainability

(10) conceptual sustainability based on continuous long-term in situ research (i.e., the constant renewal of ideas and academic leadership) for conservation. ${ }^{63}$

These principles can now be adapted and evaluated as a conceptual framework to integrate social and ecological dimensions in the Chilean long-term socio-ecological research program and elsewhere.

Finally, the Omora Park's research program involves "hybrid" disciplines, such as ethno-ecology, ecotourism, and environmental ethics. In 2004, this integration was further projected through a partnership with the Department of Philosophy and Religion Studies at the University of North Texas (UNT). Today, the park functions as a consortium between the University of Magallanes (UMAG), IEB, and the Omora Foundation in Chile with main partners in the U.S. including UNT, the Center for Environmental Philosophy (CEP), and the Omora Sub-Antarctic Research Alliance (OSARA) ${ }^{64}$ In the area of education, the incorporation of UNT and CEP into this initiative in 2004 allowed the creation of a series of international interdisciplinary field courses, entitled "Tracing Darwin's Path" and coordinated by OSARA. ${ }^{65}$ These classes include Latin American and U.S. students, and are co-taught by Chilean and U.S. scientists and philosophers. They allow a direct experience and first-hand learning opportunity for students to apply their study of environmental ethics and biocultural diversity to the actual interdisciplinary approaches that Omora is implementing in the Cape Horn Biosphere Reserve. Building on these pioneering efforts, the new Chilean long-term socio-ecological research network now should work to implement interdisciplinary field education as a transversal program among all the sites.

\section{CONCLUSIONS}

A review of the history of long-term ecological research shows that these programs arose from and responded to historical currents within the discipline of ecology, but also to changing administrative and political structure of science related to awareness of the role of humans in the functioning of the biosphere. The genesis of long-term ecological research made large-scale manipulative ecosystem experiments possible, which in turn necessitated medium- and long-term funding cycles

\footnotetext{
${ }^{63}$ Rozzi et al., "Ten Principles for Biocultural Conservation."

${ }^{64}$ See http://www.chile.unt.edu.

${ }^{65}$ See http://www.chile.unt.edu/studyabroad/index.htm and http://www.osara.org.
} 
and cross-site comparisons to address relevant questions from both a disciplinary and society perspective. ${ }^{66}$ Recently, concerted efforts seek to integrate the social sciences into long-term ecological research, ${ }^{67}$ and extend their scope to rural, agricultural and urban areas, ${ }^{68}$ as well as pristine remote areas, in a context of global change, thus demanding the inclusion of the human-dimension of ecology. In some developing countries, long-term ecological research sites have included people and linked science with decision-making. The creation of the Chilean long-term socioecological research network offers a platform to develop new models for linking natural sciences, social sciences, the humanities, and policy concerns. It should take into account these trends and installs itself at the vanguard of efforts to conduct socially relevant, long-term research on coupled human and natural systems. In the context of global ecological and social changes, existing international and interdisciplinary partnerships also represent a strength of this nascent long-term socio-ecological research network.

Traditional funding cycles and administrative research structures often favor narrow discipline-specific indicators of success, such as ISI, ${ }^{69}$ which may not adequately reward long-term interdisciplinary approaches, whose benefits accrue over time and are not reflected only in those disciplinary indices. Participants and coordinators of the Chilean long-term socio-ecological research network must demonstrate to funding agencies the need to create new indices to assess and validate this new type of academic endeavor. The Chilean long-term socio-ecological research network provides IEB a unique opportunity to legitimize the role of research and ecological education in social processes and dialogue, rather than academics talking to the broader community. IEB can help the Chilean and international academic community move from restrictive evaluation criteria and a focus solely on basic research and monitoring into broader intellectual and practical realms, which better reflect eco-social integration.

Finally, lack of infrastructure, controlled study sites, the national financial-evaluation structure for science and instability in university and governmental policies prevented an earlier formal implementation of long-term research in Chile..$^{70}$ IEB will have to overcome these barriers in order to promote transdisciplinary teams and joint multi-institutional research projects and achieve broader goals facilitated

\footnotetext{
${ }^{66}$ Golley, A History of the Ecosystem Concept, Franklin et al., "Contributions of the Long-Term Ecological Research Program," and Hobbie et al., "The U.S. Long-Term Ecological Research Program."

${ }^{67}$ Redman et al., "Integrating Social Science into the Long-Term Ecological Research (LTER) Network."

${ }^{68}$ N. B. Grimm, J. M. Grove, S. T. A. Pickett, and C. L. Redman, "Integrated Approaches to LongTerm Studies of Urban Ecological Systems," BioScience 50 (2000): 571-84.

${ }^{69}$ Institute for Scientific Information, which manages a widely used database that records indexed, peer-reviewed publications and the number of citations of published papers by author is often considered an indicator of scientific production.

${ }^{70}$ J. J. Armesto, "Fundamentos y Necesidades para un Programa de Estudios de Largo Plazo de Ecología en Chile," Revista Chilena de Historia Natural 68 (1995): 5-11.
} 
by this new long-term socio-ecological research network. ${ }^{71}$ This network will also stimulate a more participatory role for science in decision making and the application of knowledge, instead of the traditional "scientist informant" roles. ${ }^{72}$ Long-term commitment and presence is expected to help build mutual trust with local partners and insert research into local socio-political process. In this way, Chilean long-term socio-ecological research programs have the potential to help create cohesion between different disciplines in academia, and between academics and society in general.

71 J. A. Drew and A. P. Henne, "Conservation Biology and Traditional Ecological Knowledge: Integrating Academic Disciplines for Better Conservation Practice," Ecology and Society 11 (2006) at http://www.ecologyandsociety.org/vol11/iss2/art34. 